\title{
The Development of ZnO Nanoparticle Coated Cotton Fabrics for Antifungal and Antibacterial Applications
}

\author{
Tanu Shree Roy ${ }^{1}$, Siraj Ud Daula Shamim², Md. Khalidur Rahman ${ }^{3}$, F. Ahmed ${ }^{4}$, M. A. Gafur ${ }^{5 *}$ \\ ${ }^{1}$ Department of Physics, Bangladesh University of Textile, Dhaka, Bangladesh \\ ${ }^{2}$ Department of Physics, Mawlana Bhashani Science and Technology University, Tangail, Bangladesh \\ ${ }^{3}$ Department of Electrical \& Electronic Engineering, Prime University, Dhaka, Bangladesh \\ ${ }^{4}$ Department of Physics, Jahangirnagar University, Saver, Dhaka, Bangladesh \\ ${ }^{5}$ PP \& PDC, Bangladesh Council of Scientific \& Industrial Research (BCSIR), Dhaka, Bangladesh \\ Email: ^dr.abdul.gafur999@gmail.com
}

How to cite this paper: Roy, T.S., Shamim, S.U.D., Rahman, M.K., Ahmed, F. and Gafur, M.A. (2020) The Development of $\mathrm{ZnO}$ Nanoparticle Coated Cotton Fabrics for Antifungal and Antibacterial Applications. Materials Sciences and Applications, 11, 601-610.

https://doi.org/10.4236/msa.2020.119040

Received: May 19, 2020

Accepted: September 6, 2020

Published: September 9, 2020

Copyright $\odot 2020$ by author(s) and Scientific Research Publishing Inc. This work is licensed under the Creative Commons Attribution International License (CC BY 4.0).

http://creativecommons.org/licenses/by/4.0/

\section{(c) (i) Open Access}

\begin{abstract}
In the textile industry, cotton is the most popular choice among all the natural fibers due to its unique properties such as softness, affinity to skin, biodegradability, absorbency, and moisture being comfortable to wear. Zinc Oxide Nanoparticles ( $\mathrm{ZnO}$ NPs) were produced and coated on cotton fabrics. The concentration of Zinc acetate was varied. 2-methoxy-ethanol has been used as a solvent. Using the dip coating technique, $\mathrm{ZnO}$ NPs have been coated on the cotton fabric in different mole concentrations. Scanning Electron Microscopy (SEM), Ultraviolet Visible (UV-VIS) spectroscopy, the antifungal and antibacterial activity of the $\mathrm{ZnO}$ NPs was performed on the coated fabrics. The SEM images depicted that the nanoparticles are well dispersed on the fabric at $3 \mathrm{M}$ concentration of $\mathrm{ZnO}$ solution. It was found that the UV absorbance increases with the increase of concentration up to $2 \mathrm{M}$ concentration and after that it decreases. It was also found that maximum antibacterial and antifungal activity is at $2 \mathrm{M}$ concentration.
\end{abstract}

\section{Keywords}

Nanoparticles, ZnO, Cotton, SEM, UV-VIS, Antibacterial, Antifungal

\section{Introduction}

Due to the surface effect and quantum size effect, nanoparticles exhibit exceptional physical, chemical, optical properties from bulk materials [1] [2]. This 
leads to different applications in drugs and medicines, environment, electronics, food, manufacturing and materials, mechanical industries [3] [4] [5] [6]. From the literature reviews, it has been found that the nanoparticles such as $\mathrm{Ag}, \mathrm{ZnO}$, $\mathrm{CuO}, \mathrm{TiO}_{2}, \mathrm{SiO}_{2} \mathrm{NPs}$, etc. are widely used in the textile engineering sector for enhancing the performance of water repellency, flame retardancy [7], breathability, self-cleaning [8], antibacterial effect [9], UV protection [6], etc. Ag NPs has been widely used as an antibacterial agent on fabric against Staphylococcus aureus and Escherichia coli bacteria [10]. $\mathrm{TiO}_{2}$ and $\mathrm{SiO}_{2} \mathrm{NPs}$ have been used for imparting for self-cleaning property [11] [12]. Among these nanoparticles, $\mathrm{ZnO}$ NPs is widely used for antibacterial properties, photo-catalytic properties, UV blocking properties due to nontoxicity, biosafety, chemically stable under exposure to both high temperature and UV [13] [14]. Although the small doses of UV radiation from the sun provide vitamin $\mathrm{D}$ that can contribute to bone development, the intense UV radiation can cause skin cancer, Alzheimer's diseases, inflammatory disorders, etc. which is harmful to our outdoor workers [15] [16]. Therefore, NPs are used to protect the UV rays from the sun by coating on fabrics.

Among the total fibers used in the textile industry, about $48 \%$ of cotton fibers are used around the world due to its excellent properties such as hygroscopicity, air permeability, softness, breathability, bio-degradation, regeneration, no static electricity, etc. [17] [18] [19]. It is an abundant natural renewable fiber that consists of about $88 \%$ - $96 \%$ of pure cellulose [20] [21]. As cotton fabrics have a high specific surface area and have the ability to retain moisture, microorganisms can grow easily into the cotton fabric [22] [23]. To get rid of microorganisms, numerous chemical agents have been coated on the fabrics. Among these chemical agents, $\mathrm{ZnO}$ NPs shows strong inhibitory and antibacterial effects against Staphylococcus aureus and Escherichia coli, etc. [24]. In 2016, Shaban M et al. synthesized ZnO NPs by using the sol-gel method and coated ZnO NPs on cotton fabric via a spin coating technique. They found that $\mathrm{ZnO}$ NPs showed high photocatalytic activity and self-cleaning property against methyl orange dye under the sunlight and lamp illumination [25]. Becheri Alessio et al. synthesized and characterized $\mathrm{ZnO}$ NPs and coated on cotton and wool fabrics for UV shielding. They claimed that a significant increment of the UV absorbing activity due to coating $\mathrm{ZnO}$ NPs on the cotton and wool fabrics can protect our body from solar radiation [26]. Rajendra R. et al. prepared ZnO NPs and coated on cotton fabric by wet chemical method and investigated the antimicrobial property. They clearly confirmed that the $\mathrm{ZnO}$ NPs treated fabrics showed a better antibacterial effect than the bulk $\mathrm{ZnO}$ against $S$. aureus and E. coli [24].

In this study, the $\mathrm{ZnO}$ solution has been prepared by using a chemical method. Different mole concentrations $(1 \mathrm{M}, 1.5 \mathrm{M}, 2 \mathrm{M}, 2.5 \mathrm{M}$, and $3 \mathrm{M})$ have been prepared and dip-coated on the cotton fabric for enhancing the UV-VIS spectroscopy, antifungal, and antibacterial properties. We have investigated the change of properties with varying mole concentrations. The morphological characteristic, UV-VIS spectroscopy, antifungal and antibacterial properties of $\mathrm{ZnO}$ 
solution coated cotton fabric has been examined by Scanning Electron Microscopy (SEM), Ultraviolet-Visible (UV-VIS) spectroscopy, disk diffusion methods respectively.

\section{Experimental Details}

\subsection{Materials}

Zinc acetate dehydrate $\left(\mathrm{Zn}\left(\mathrm{CH}_{3} \mathrm{COO}\right)_{2} \cdot 2 \mathrm{H}_{2} \mathrm{O}\right)$, 2-methoxyethanol $\left(\mathrm{C}_{3} \mathrm{H}_{8} \mathrm{O}_{2}\right)$ and monoethanolamine $\left(\mathrm{C}_{2} \mathrm{H}_{7} \mathrm{NO}\right)$ were purchased from Merck-chemicals (Germany). Woven and scoured cotton fabric was obtained from a testing laboratory of BUTEX, Bangladesh. Aspergillus niger, Staphylococcus aureus and Escherichia coli were obtained from WAFFEN Research Laboratory, Dhaka, Bangladesh. Distilled water was utilized throughout the whole research work.

\subsection{Washing of the Cotton Fabric}

To remove the impurities such as wax and fat, the cotton fabric was washed first with water and detergent at $80^{\circ} \mathrm{C}$ for $30 \mathrm{~min}$. Then it was washed 3 times with a sufficient amount of deionized water and further cleaned with acetone at $60^{\circ} \mathrm{C}$ $70^{\circ} \mathrm{C}$ about $30 \mathrm{~min}$. The same cleaning was performed with ethanol flowed by drying at room temperature for $24 \mathrm{~h} \mathrm{[25].}$

\subsection{Preparation of $\mathrm{ZnO}$ Solution}

Zinc acetate dihydrate, 2-methoxyethanol, and monoethanolamine were used as a precursor, solvent and stabilizer respectively. The molar ratio of monoethanolamine to zinc acetate dihydrate was maintained at a 1:1 molar ratio where solvent 2-methoxyethanol was used as much as needed to prepare $1 \mathrm{M}, 1.5 \mathrm{M}, 2 \mathrm{M}$, $2.5 \mathrm{M}$ and $3 \mathrm{M}$ concentrations [25]. For example, $5.4875 \mathrm{gm}$ Zinc acetate dihydrate, 1.527 gm monoethanolamine and $25 \mathrm{ml}$ 2-methoxyethanol were used for preparing $1 \mathrm{M}$ concentration $\mathrm{ZnO}$ Solution. Similarly, different concentration solutions were prepared and the solutions were acquired after stirring at $60^{\circ} \mathrm{C}$ for $2 \mathrm{~h}$ at $500 \mathrm{rpm}$ stirring rate. Then the solutions were aged for 24 hours at room temperature before the coating process on the cotton fabric. Figure 1 shows the flowchart of the preparation of ZnO NPs.

\subsection{Coating Process}

In this study, dip coating has been carried out for coating $\mathrm{ZnO}$ solution on the cotton fabric. In this process, fabric was dipped at room temperature for $60 \mathrm{sec}$ into the $\mathrm{ZnO}$ solution. Then it was dried at $80^{\circ} \mathrm{C}$ for $30 \mathrm{~min}$ in a drier to get rid of the excess 2-methoxyethanol and monoethanolamine residuals in vacuum oven at 150 mbar pressure. The process was done by dip coater (TL0.01 Dip Coater, MTI Corporation, USA). The process is composed manually dipping and withdrawing at speed of $30 \mathrm{~cm} / \mathrm{min}$ [26]. The dipping is a manual operation. These coating steps were repeated for ten times and finally the dried fabrics were annealed in a furnace at $150^{\circ} \mathrm{C}$ in air for $2 \mathrm{~h} \mathrm{[25].}$ 


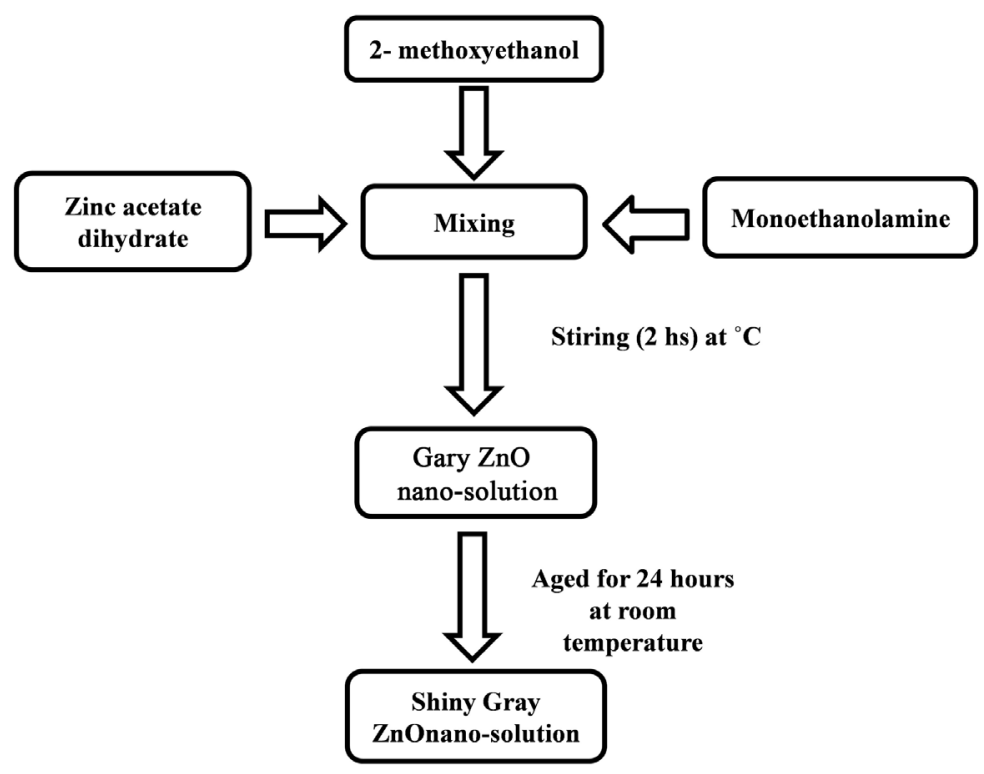

Figure 1. Flowchart of preparation of the $\mathrm{ZnO}$ nano solution from Zinc acetate dihydrate, 2-methoxyethanol and monoethanolamine.

\subsection{Samples Characterization}

The surface morphology of $\mathrm{ZnO}$ nanoparticle coated cotton fabrics was measured by scanning electron microscopy (EVO18, Carl Zeiss AG, Germany). The absorption spectra of $\mathrm{ZnO}$ solution and $\mathrm{ZnO}$ NPs coated cotton fabrics were obtained from ultraviolet-visible (UV-VIS) spectrometer (UV-VIS-1601, Shimadzu, Japan) with a wavelength range from 300 to $920 \mathrm{~nm}$. The antifungal activity against aspergillusniger and antibacterial activity against Staphylococcus aureus (gram positive) and Escherichia coli (gram negative) of the ZnO NPs were performed on the coated fabrics by disk diffusion method.

\section{Results and Discussions}

\subsection{Scanning Electron Microscopy (SEM)}

Figure 2 shows the SEM micrographs of $\mathrm{ZnO}$ coated cotton fabric at various concentrations of $\mathrm{ZnO}$. From the figure, it is found that concentration of $\mathrm{ZnO}$ has a significant effect on the morphology of the $\mathrm{ZnO}$ coated cotton fabric. In case of $1 \mathrm{M}, 2 \mathrm{M}$ and $2.5 \mathrm{M} \mathrm{ZnO}$ solutions coated cotton fabric, the nanoparticles are not well dispersed on the cotton fabric and the surface of the fabric is smooth in comparison with $3 \mathrm{M} \mathrm{ZnO}$ solutions coated cotton fabric. It has appeared that the nanoparticles are aggregated on the cotton fabric in case of $1 \mathrm{M}, 2 \mathrm{M}$ and $2.5 \mathrm{M} \mathrm{ZnO}$ concentration. The size of nanoparticles plays a vital role in the fibers. The larger the size of nanoparticles, lesser adhesion to the cotton fabric and easily removed from the fabric during washing. And smaller particles strongly adhere and penetrate deeper into the fabric [27]. The SEM image of $3 \mathrm{M}$ $\mathrm{ZnO}$-coated cotton fabric indicates that it is completely different. For $3 \mathrm{M} \mathrm{ZnO}$ solution, the SEM image depicts that the $\mathrm{ZnO}$ nanoparticles are adsorbed 


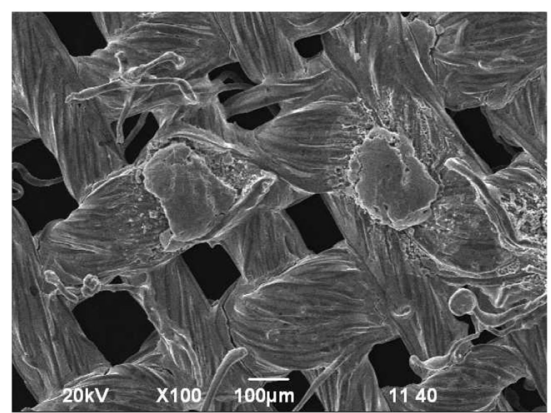

(a)

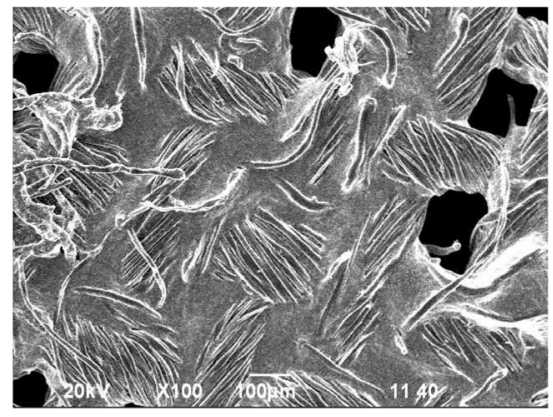

(c)

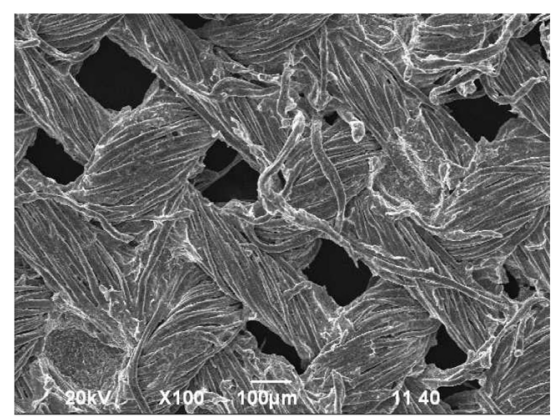

(b)

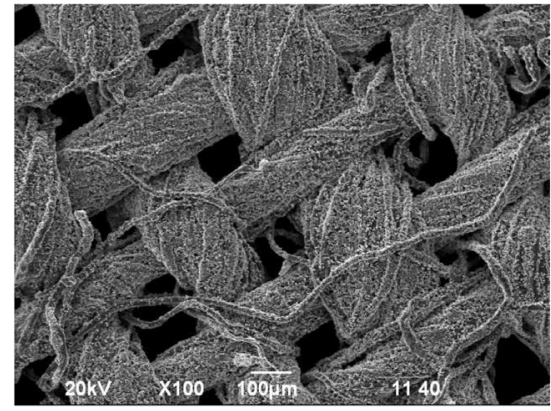

(d)

Figure 2. SEM images of the (a) $1 \mathrm{M}$, (b) $2 \mathrm{M}$, (c) $2.5 \mathrm{M}$ and (d) $3 \mathrm{M} \mathrm{ZnO}$-coated cotton fabrics respectively.

on cotton fabric homogeneously as compared with other mole concentrations due to hydroxyl group present in cotton fabric i.e. the nanoparticles are well dispersed on the fabric [28].

\subsection{Ultraviolet-Visible (UV-VIS) Spectroscopy Analysis}

Figure 3 illustrates the variation of absorption spectra with wavelength. In case of $\mathrm{ZnO}$ solutions, it shows UV-VIS absorption properties and typical peaks have been found in the region of 330 to $350 \mathrm{~nm}$ wavelength range which is similar with the previously reported $\mathrm{ZnO}$ samples [27]. With the increasing concentrations, the absorption of UV rays is increased drastically. Herein, $1 \mathrm{M} \mathrm{ZnO}$ has provided lowest absorbance while $2 \mathrm{M} \mathrm{ZnO}$ has given highest absorbance. Interestingly, the absorption property is greatly enhanced from $1 \mathrm{M}$ to $2 \mathrm{M}, 2.5 \mathrm{M}$ and $3 \mathrm{M}$ solutions. $2 \mathrm{M}, 2.5 \mathrm{M}$ and $3 \mathrm{M} \mathrm{ZnO}$ solutions have been shown comparable absorption properties. Thus the UV absorbance increases with the increase of concentration up to $2 \mathrm{M}$ concentration and after that it decreases. It occurs due to that up to $2 \mathrm{M}$ concentration, the solution remains homogeneous but above $2 \mathrm{M}$ concentration, the nanoparticles in the solution aggregate to form larger radius particles and may falls down. Thus, the absorbency slightly decreases.

But after coating with different concentrations of $\mathrm{ZnO}$ solutions on the cotton fabric, it is found that, $2 \mathrm{M}$ and $2.5 \mathrm{M} \mathrm{ZnO}$ coated cotton fabric have shown significant absorbance properties. Among these various concentrations, $2.5 \mathrm{M} \mathrm{ZnO}$ coated cotton fabric has absorbed highest UV-VIS rays while $3 \mathrm{M} \mathrm{ZnO}$ coated 


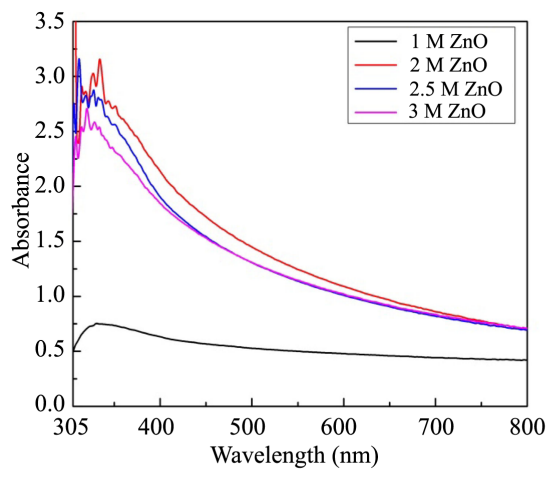

(a)

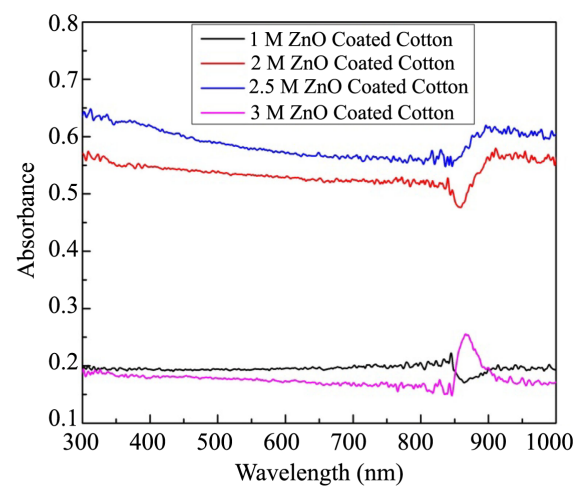

(b)

Figure 3. Absorption spectra of (a) $1 \mathrm{M}, 2 \mathrm{M}, 2.5 \mathrm{M}$ and $3 \mathrm{M} \mathrm{ZnO}$ nanoparticles containing solutions and (b) $1 \mathrm{M}, 2 \mathrm{M}, 2.5 \mathrm{M}$ and $3 \mathrm{M} \mathrm{ZnO}$-coated cotton fabrics.

cotton fabric has absorbed the lowest UV-VIS rays. So, it can be concluded that $2.5 \mathrm{M}$ concentration of $\mathrm{ZnO}$ nanoparticle is the optimum concentration for the $\mathrm{ZnO}$ nano particle coated cotton fabrics to absorb UV-VIS rays.

\subsection{Antifungal and Antibacterial Activity Analysis}

Zone of inhibition indicates a circular area where bacteria or fungal do not grow. In our study, we have taken one fungal (Aspergillus niger) and two bacteria (Staphylococcus aureus and Escherichia coli) to test antifungal and antibacterial effect by "Disk Diffusion Method".

Figure 4 depicts the effect of concentration of $\mathrm{ZnO}$ NPs on the zone of inhibition for coated cotton fabric and Figure 5 shows the pictorial view of inhibition zone for the same. In this study, pure cotton fabric do not exhibit zone of inhibition. But after coating $\mathrm{ZnO}$ nanoparticles on the cotton fabric, strong zone of inhibition have been found against Aspergillus niger, Staphylococcus aureus and Escherichia coli. It means, $\mathrm{ZnO}$ nanoparticles act as antifungal and antibacterial agent [29] [30].

In case of antifungal effect, according to this graph, pure cotton has shown no zone of inhibition where $2 \mathrm{M} \mathrm{ZnO}$ coated cotton fabric has shown the highest zone of inhibition $(14 \mathrm{~mm})$. The $2.5 \mathrm{M} \mathrm{ZnO}$ coated cotton fabric has shown a lower zone of inhibition with comparison to $2 \mathrm{M} \mathrm{ZnO}$ coated cotton fabric and the $3 \mathrm{M} \mathrm{ZnO}$ coated cotton fabric has shown a lower zone of inhibition with comparison to $2.5 \mathrm{M} \mathrm{ZnO}$ coated cotton fabric. So, $2 \mathrm{M}$ is the optimum concentration of $\mathrm{ZnO}$ for the $\mathrm{ZnO}$ coated cotton fabrics for the antifungal effect against Aspergillus niger.

Similarly, antibacterial activity of the $\mathrm{ZnO}$ coated cotton fabrics has been investigated for the "Staphylococcus aureus" (gram positive) and "Escherichia coli" (gram negative) bacterias. For antibacterial effect against "Staphylococcus aureus", pure cotton has shown no zone of inhibition where $2 \mathrm{M} \mathrm{ZnO}$ coated cotton fabric has shown the highest zone of inhibition $(24.5 \mathrm{~mm})$. The $2.5 \mathrm{M}$ $\mathrm{ZnO}$ coated cotton fabric has shown a lower zone of inhibition with comparison 


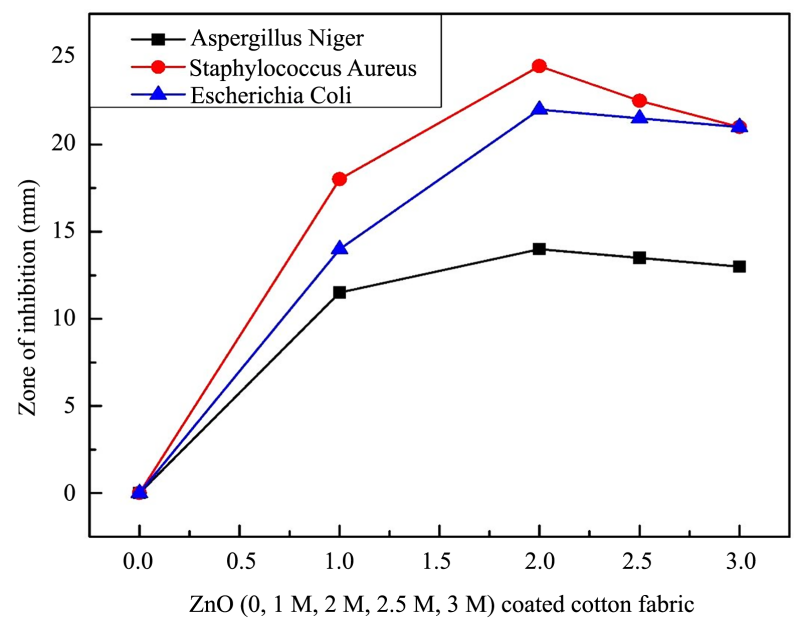

Figure 4. Zone of Inhibition is plotted against different concentrations of the $\mathrm{ZnO}$ coated Cotton Fabrics for the Aspergillus niger, Staphylococcus aureus and Escherichia coli.

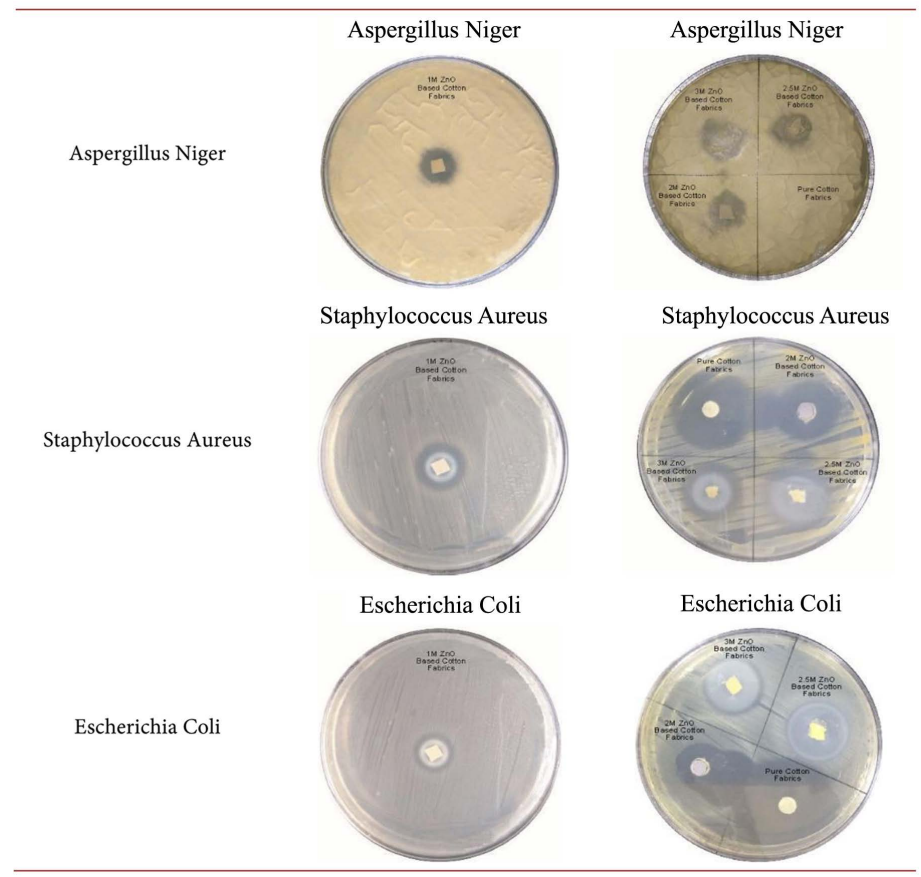

Figure 5. Zone of inhibition of pure, $1 \mathrm{M}, 2 \mathrm{M}, 2.5 \mathrm{M}$ and $3 \mathrm{M} \mathrm{ZnO}$ nano-solution coated cotton fabric against Aspergillus niger, Staphylococcus aureus and Escherichia coli.

to $2 \mathrm{M} \mathrm{ZnO}$ coated cotton fabric and the $3 \mathrm{M} \mathrm{ZnO}$ coated cotton fabric has shown a lower zone of inhibition with comparison to $2.5 \mathrm{M} \mathrm{ZnO}$ coated cotton fabric. So, $2 \mathrm{M}$ is the optimum concentration of $\mathrm{ZnO}$ for the $\mathrm{ZnO}$ coated cotton fabrics for the antibacterial effect against Staphylococcus aureus. Similar results have been found for Escherichia coli bacteria. Here in, 2M, 2.5M and 3M ZnO coated cotton fabrics have shown an analogous zone of inhibition about $22 \mathrm{~mm}, 21.5$ $\mathrm{mm}$ and $21 \mathrm{~mm}$ respectively. But $2 \mathrm{M} \mathrm{ZnO}$ coated cotton fabric has shown the 
highest zone of inhibition. So $2 \mathrm{M}$ is the optimum concentration of $\mathrm{ZnO}$ for the $\mathrm{ZnO}$ coated cotton fabrics for the antibacterial effect against Escherichia coli. Therefore, with increasing the concentration of $\mathrm{ZnO}$ nano-solution, the antifungal and antibacterial activity increased upto $2 \mathrm{M}$ with significant zone of inhabitation which is consistent with previous works [31] [32], such as Valery Svetlichnyi et al. found highest $\sim 27 \mathrm{~mm}$ and $\sim 18 \mathrm{~mm}$ zone of inhabitation for Escherichia coli and Staphylococcus aureus bacteria [30]. Therefore, it is expected that the $\mathrm{ZnO}$ nano particle coated cotton fabric can be used in medical applications such as disposable bedding linen, antibacterial bandage and uniforms for health worker etc. since it exhibits bacterial effect [29] [30].

\section{Conclusion}

This work describes the methods and results obtained in the development of $\mathrm{ZnO}$ nanoparticle coated cotton fabrics for antifungal and antibacterial applications. Characterization of nanoparticles obtained and incorporated into the cotton fabric is shown using Scanning Electron Microscopy (SEM) and Ultraviolet-Visible (UV-VIS) Spectroscopy Analysis methods, to different concentrations of $\mathrm{ZnO}$. Zone of inhibition is found in samples of cotton fabrics with different bacteria, using the disk diffusion method. It was also found that maximum antibacterial and antifungal activity is at $2 \mathrm{M}$ concentration of $\mathrm{ZnO}$.

\section{Conflicts of Interest}

The authors declare no conflicts of interest regarding the publication of this paper.

\section{References}

[1] Roduner, E. (2006) Size Matters: Why Nanomaterials Are Different. Chemical Society Reviews, 35, 583-592. https://doi.org/10.1039/b502142c

[2] Shameli, K., Ahmad, M.B., Yunus, W.M.Z.W., et al. (2010) Green Synthesis of Silver/Montmorillonite/Chitosan Bionanocomposites Using the UV Irradiation $\mathrm{Me}$ thod and Evaluation of Antibacterial Activity. International Journal of Nanomedicine, 5, 875-887. https://doi.org/10.2147/IJN.S13632

[3] Stark, W.J., Stoessel, P.R., Wohlleben, W., et al. (2015) Industrial Applications of Nanoparticles. Chemical Society Reviews, 44, 5793-5805. https://doi.org/10.1039/C4CS00362D

[4] Shipway, A.N., Katz, E. and Willner, I. (2000) Nanoparticle Arrays on Surfaces for Electronic, Optical, and Sensor Applications. Angewandte Chemie (International Ed. English), 1, 19-52. https://doi.org/10.1002/1439-7641(20000804)1:1<18::AID-CPHC18>3.0.CO;2-L

[5] Hofmann-Amtenbrink, M., Grainger, D.W. and Hofmann, H. (2015) Nanoparticles in Medicine: Current Challenges Facing Inorganic Nanoparticle Toxicity Assessments and Standardizations. Nanomedicine: Nanotechnology, Biology and Medicine, 11, 1689-1694. https://doi.org/10.1016/j.nano.2015.05.005

[6] Subbiah, D.K., Mani, G.K., Babu, K.J., et al. (2018) Nanostructured ZnO on Cotton Fabrics-A Novel Flexible Gas Sensor \& UV Filter. Journal of Cleaner Production, 
194, 372-382. https://doi.org/10.1016/j.jclepro.2018.05.110

[7] Alongi, J., Carosio, F., Frache, A., et al. (2013) Layer by Layer Coatings Assembled through Dipping, Vertical or Horizontal Spray for Cotton Flame Retardancy. Carbohydrate Polymers, 92, 114-119. https://doi.org/10.1016/j.carbpol.2012.08.086

[8] Akhavan Sadr, F. and Montazer, M. (2014) In Situ Sonosynthesis of $\mathrm{Nano}^{\mathrm{TiO}}{ }_{2}$ on Cotton Fabric. Ultrasonics Sonochemistry, 21, 681-691. https://doi.org/10.1016/j.ultsonch.2013.09.018

[9] Emam, H.E., Saleh, N.H., Nagy, K.S., et al. (2015) Functionalization of Medical Cotton by Direct Incorporation of Silver Nanoparticles. International Journal of Biological Macromolecules, 78, 249-256. https://doi.org/10.1016/j.ijbiomac.2015.04.018

[10] Lee, H.J., Yeo, S.Y. and Jeong, S.H. (2003) Antibacterial Effect of Nanosized Silver Colloidal Solution on Textile Fabrics. Journal of Materials Science, 38, 2199-2204.

[11] Qi, K., Chen, X., Liu, Y., et al. (2007) Facile Preparation of Anatase/SiO ${ }_{2}$ Spherical Nanocomposites and Their Application in Self-Cleaning Textiles. Journal of Materials Chemistry, 17, 3504-3508. https://doi.org/10.1039/b702887c

[12] Xin, J.H., Daoud, W.A. and Kong, Y.Y. (2004) A New Approach to UV-Blocking Treatment for Cotton Fabrics. Textile Research Journal, 74, 97-100. https://doi.org/10.1177/004051750407400202

[13] Hatamie, A., Khan, A., Golabi, M., et al. (2015) Zinc Oxide Nanostructure-Modified Textile and Its Application to Biosensing, Photocatalysis, and as Antibacterial Material. Langmuir, 31, 10913-10921. https://doi.org/10.1021/acs.langmuir.5b02341

[14] El-Naggar, M.E., Shaarawy, S. and Hebeish, A.A. (2018) Multifunctional Properties of Cotton Fabrics Coated with in Situ Synthesis of Zinc Oxide Nanoparticles Capped with Date Seed Extract. Carbohydrate Polymers, 181, 307-316. https://doi.org/10.1016/j.carbpol.2017.10.074

[15] Serrano, M.A., Cañada, J. and Moreno, J.C. (2013) Solar UV Exposure in Construction Workers in Valencia, Spain. Journal of Exposure Science \& Environmental Epidemiology, 23, 525-530. https://doi.org/10.1038/jes.2012.58

[16] Wright, F. and Weller, R.B. (2015) Risks and Benefits of UV Radiation in Older People: More of a Friend than a Foe? Maturitas, 81, 425-431. https://doi.org/10.1016/j.maturitas.2015.05.003

[17] Ding, Z., Dong, Y. and Li, B. (2012) Preparation of a Modified PTFE Fibrous Photo-Fenton Catalyst and Its Optimization towards the Degradation of Organic Dye. International Journal of Photoenergy, 2012, Article ID: 121239. https://doi.org/10.1155/2012/121239

[18] Epps, H.H. (2003) Basic Principles of Textile Coloration. Color Research \& Application, 28, 230-231. https://doi.org/10.1002/col.10152

[19] Ibrahim, N.A., Eid, B.M., El-Aziz, E.A., et al. (2017) Loading of Chitosan-Nano Metal Oxide Hybrids onto Cotton/Polyester Fabrics to Impart Permanent and Effective Multifunctions. International Journal of Biological Macromolecules, 105, 769-776. https://doi.org/10.1016/j.ijbiomac.2017.07.099

[20] Rattanaphani, S., Chairat, M., Bremner, J.B., et al. (2007) An Adsorption and Thermodynamic Study of Lac Dyeing on Cotton Pretreated with Chitosan. Dyes and Pigments, 72, 88-96. https://doi.org/10.1016/j.dyepig.2005.08.002

[21] (2007) Hawley's Condensed Chemical Dictionary. Hawley's Condens. Chem. Dict.

[22] Shahidi, S. and Ghoranneviss, M. (2016) Plasma Sputtering for Fabrication of Antibacterial and Ultraviolet Protective Fabric. Cloth. Textile Research Journal, 34, 
37-47. https://doi.org/10.1177/0887302X15594455

[23] Yildiz, A., Atav, R., Oztas, M., et al. (2015) Synthesis of Silver Mono- and Di-Carboxylates and Investigation of Their Usage Possibility in Textiles as an Antibacterial Agent. Fibres \& Textiles in Eastern Europe, 23, 120-125. https://doi.org/10.5604/12303666.1152550

[24] Rajendra, R., Balakumar, C., Ahammed, H., et al. (2010) Use of Zinc Oxide Nano Particles for Production of Antimicrobial Textiles. International Journal of Engineering, Science and Technology, 2, 202-208. https://doi.org/10.4314/ijest.v2i1.59113

[25] Shaban, M., Abdallah, S. and Khalek, A.A. (2016) Characterization and Photocatalytic Properties of Cotton Fibers Modified with ZnO Nanoparticles Using Sol-Gel Spin Coating Technique. Beni-Suef University Journal of Basic and Applied Sciences, 5, 277-283. https://doi.org/10.1016/j.bjbas.2016.08.003

[26] Mahltig, B. and Textor, T. (2006) Combination of Silica Sol and Dyes on Textiles. Journal of Sol-Gel Science and Technology, 39, 111-118. https://doi.org/10.1007/s10971-006-7744-9

[27] Becheri, A., Dürr, M., Lo Nostro, P., et al. (2008) Synthesis and Characterization of Zinc Oxide Nanoparticles: Application to Textiles as UV-Absorbers. Journal of Nanoparticle Research, 10, 679-689. https://doi.org/10.1007/s11051-007-9318-3

[28] Gardner, D.J., Oporto, G.S., Mills, R., et al. (2008) Adhesion and Surface Issues in Cellulose and Nanocellulose. Journal of Adhesion Science and Technology, 22, 545-567. https://doi.org/10.1163/156856108X295509

[29] Pandimurugan, R. and Thambidurai, S. (2017) UV Protection and Antibacterial Properties of Seaweed Capped $\mathrm{ZnO}$ Nanoparticles Coated Cotton Fabrics. International Journal of Biological Macromolecules, 105, 788-795. https://doi.org/10.1016/j.ijbiomac.2017.07.097

[30] Singh, G., Joyce, E., Beddow, J., et al. (2019) Evaluation of Antibacterial Activity of Zno Nanoparticles Coated Sonochemically onto Textile Fabrics. Journal of Microbiology, Biotechnology and Food Sciences, 9, 106-120.

[31] Svetlichnyi, V., Shabalina, A., Lapin, I., et al. (2016) ZnO Nanoparticles Obtained by Pulsed Laser Ablation and Their Composite with Cotton Fabric: Preparation and Study of Antibacterial Activity. Applied Surface Science, 372, 20-29. https://doi.org/10.1016/j.apsusc.2016.03.043

[32] Borda D’Água, R., Branquinho, R., Duarte, M.P., et al. (2018) Efficient Coverage of $\mathrm{ZnO}$ Nanoparticles on Cotton Fibres for Antibacterial Finishing Using a Rapid and Low Cost: In Situ Synthesis. New Journal of Chemistry, 42, 1052-1060. https://doi.org/10.1039/C7NJ03418K 